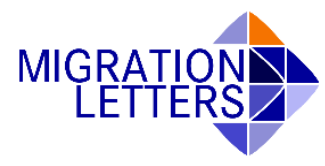

First Submitted: 15 March 2020 Accepted: 1 April 2020

DOI: https://doi.org/10.33182/ml.v17i2.935

\title{
Coronavirus and Migration: Analysis of Human Mobility and the Spread of COVID-19
}

\author{
Ibrahim Sirkeci ${ }^{1}$ and M. Murat Yüceşahin ${ }^{2}$
}

\begin{abstract}
Reactions, measures as well as discourses dealing with the current pandemic vary significantly across the world. While some countries were completely locked down, as was the case in Italy, some had claimed to have very few or no cases, as was the case in Turkey and Indonesia by March 10th, 2020. Nevertheless, the spread of COVID-19 from China has been clearly linked to those travelling from Wuhan in Hubei province in Central China. Therefore, it is important to understand the travel density/volume of passengers carried as well as routes from Wuhan through connected main regional air travel hubs across China. In this study, we developed a model on migration and travel intensity that can explain outbreak and spread of COVID-19 since it appeared at the end of 2019. We show that the presence of migrant stock populations of Chinese origin and the immigrant stock in China are useful indicators in the prediction of the spread of the outbreak worldwide in the event of interaction with several other macro factors. We argue that monitoring immigrant stock data and travel volume data based on human mobility corridors (i.e. origins and destinations), countries could have been better prepared and taken early measures to contain the spread of COVID-19.
\end{abstract}

Keywords: Coronavirus; COVID-19; epidemic; migration; human mobility; air travel; spatial diffusion; public health; China; Italy; France; Germany; Spain; UK; USA; Turkey.

\section{Introduction}

COVID-19 / 2019-nCoV or Coronavirus as commonly known, has probably been as terrifying as the Spanish Flu and Swine Flu (Jilani et al., 2019). We have written this article at a relatively early stage of the pandemic. Therefore, the number of cases and death toll were rising ${ }^{3}$ but not as shocking as these historic pandemics. However, still reactions, measures, as well as accompanying political discourses vary greatly across the world, while some countries are regionally locked down as was the case in Italy by $21^{\text {st }}$ of February $2020^{4}$, some others claim there is none or a few cases only as was the case in Turkey and Indonesia by 10th of March 2020.

\footnotetext{
${ }^{1}$ Professor Ibrahim Sirkeci, Director of Regents Centre for Transnational Business and Management, Regents University London, London, United Kingdom. E-mail: sirkecii@regents.ac.uk.

${ }^{2}$ Assoc. Prof. Dr. M. Murat Yüceşahin, Department of Geography, Faculty of Language and History-Geography, Ankara University, Ankara, Turkey. E-mail: mmyucesahin@gmail.com.

Acknowledgement: We would like to thank ML for fast track review and constructive feedback provided. We also thank Ş. Begüm Yüceşahin for her feedback and guidance on statistical procedures.

${ }^{3}$ Worldwide number of infected people were 666,211 along with 30,864 deaths by 29 March 2020.

${ }^{4}$ Complete, nationwide, lockdown was announced on $9^{\text {th }}$ March 2020.
} 
The origin of COVID-19 pandemic, initially, has been linked (i.e. suspected but not yet confirmed) to the cases identified in Wuhan, the capital of Hubei province in Central China. ${ }^{5}$ Therefore, it is important to take into account the travel density / volume of passengers carried and routes from Wuhan through connected main regional air travel hubs across China along with the final destinations abroad relating to many of these travellers. The travel volumes are likely to be linked to the Chinese immigrant stock populations in these destination countries following the cultures of migration model, which suggests increasing mobility and traffic between countries of destination and origin over time (Cohen and Sirkeci, 2011).

According to the World Health Organisation (WHO, 2020a), coronaviruses (CoV) are a large family of viruses that cause illness ranging from the common cold to more severe diseases, such as Middle East Respiratory Syndrome (MERS-CoV) (WHO, 2020d) and Severe Acute Respiratory Syndrome (SARS-CoV) (WHO, 2020e). The most recent coronavirus, also known as COVID-19, has not been previously observed in humans, with these types of viruses being known to be transmitted between animals and humans (WHO, 2020f). This was confirmed when the earlier cases were identified in Wuhan, China (Chan et al., 2020). Symptoms of COVID-19 are also known to be similar to common flu, but the spread is much speedier. These symptoms include fever, cough, and breathing difficulties and unfortunately can lead to death (WHO, 2020a). Therefore, the risks to public health are grave and cannot be ignored without serious risk of casualties. In sum, the COVID-19 pandemic is now a major health threat globally (Ferguson et al., 2020: 3). As of 1 April 2020 , there have been 905,279 cases and 45,371 deaths confirmed worldwide and the global spread has been extremely rapid (ECDC, 2020).

The purpose of this article is to offer insights using international migration data taking into account a series of basic macro indicators. We argue that monitoring immigrant stock data and travel volume data based on human mobility corridors (i.e. origins and destinations), countries could have been better prepared and taken much earlier measures to contain the spread of COVID-19 or other similar diseases. After introducing the conceptual framework, we explain the data and methods used, following which we discuss our findings, having mapped clusters of countries based on their profiles and numbers of COVID-19 cases. In the subsequent section, we discuss the results of a regression model, which can be used in predicting the potential spread of a pandemic, thereby providing more effective targeted and timely responses to similar outbreaks in the future. Lastly, the limitations of this study and some future avenues for research are presented.

\section{Conceptualising the Spread of Virus and Migration Relationship}

We have looked at two sets of literature to gain an understanding the current COVID-19 spread crisis: human mobility/migration literature and studies on the spatial spread of diseases. One of the models in migration literature, namely "cultures of migration", argues that over time, i.e. as migration experiences accumulate in an area and through a route between the origin and destination, mobility continues almost irrespective of changes in the drivers of migration that were in place at the beginning (Cohen and Sirkeci, 2011; Cohen, 2004). Thus, we expect an increasing volume of migration over time through established migration corridors. This can be measured by examining

\footnotetext{
5 According to a World Health Organisation report the source of the virus has not been confirmed yet (https://www.who.int/docs/default-source/coronaviruse/who-china-joint-mission-on-COVID-19-final-report.pdf), while a recent study has established two different strains of the virus: one prevalent in Wuhan, and the other being found everywhere else (https://www.researchgate.net/publication/339461351_Variant_analysis_of_COVID-19_genomes). It should be noted that, whilst the virus was first diagnosed in Wuhan this does not prove that it originated there.
} 
the volume of travel between destinations and place of origin. Therefore, we are expecting a correlation between the travel volume between a country of origin and a destination country and immigrant stock of a group in the latter. Hence, mapping the volume of migration flows from the origin of a disease can be useful in understanding the spread and thus, being equipped to set up appropriate containment measures. In the current COVID-19 crisis, this potential proxy indicator seems to be underestimated despite the mass flight cancellations declared in February and March 2020 .

It is argued that the increase in emerging infectious diseases ${ }^{6}$ is related to environmental change and to human encroachment into remote areas, which increases the contact between human and non-human species, thereby allowing for cross-species transfers of pathogens (Mayer, 2000; Anthamatten and Hazen, 2011). For example, the emergence of SARS in China in 2003 was linked to close contact between humans and the Himalayan palm civet, sold as meat in Chinese markets (Klempner and Shapiro, 2004; Anthamatten and Hazen, 2011: 41-42), whilst the most recent case of COVID-19 has been linked to bats (Lai et al., 2020a).

Disease spread patterns are known to be moderated by human activities ranging from agriculture to conflicts, however, further critical insights may be found in spatial approaches to health (Jones et al., 2008: 91; Anthamatten and Hazen, 2011: 42). Spatial approaches help us understand diffusion patterns of emerging infectious diseases. Diffusion refers to the spread of an phenomenon across space. Anthamatten and Hazen (2011) identified three primary types of diffusion (Figure 1).

Figure 1. Three types of spatial-diffusion patterns of viruses and/or contagious diseases

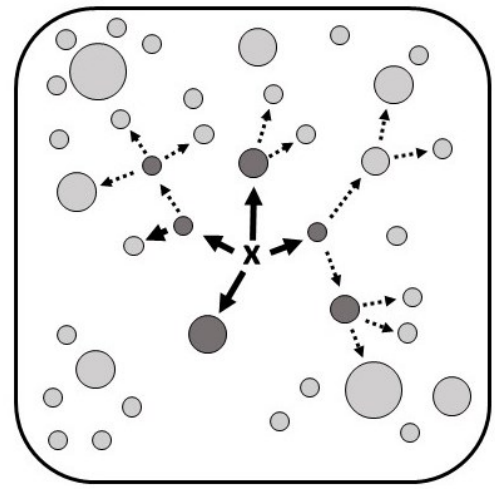

(a)

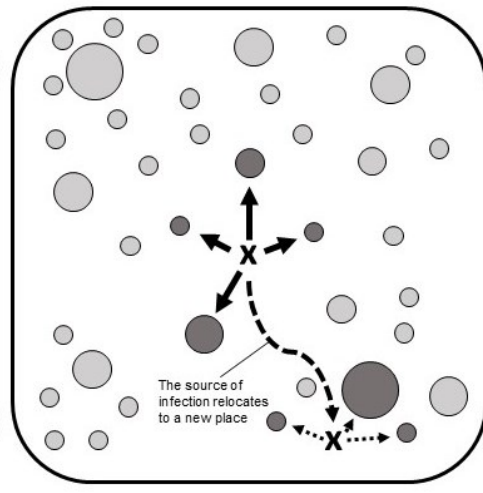

(b)

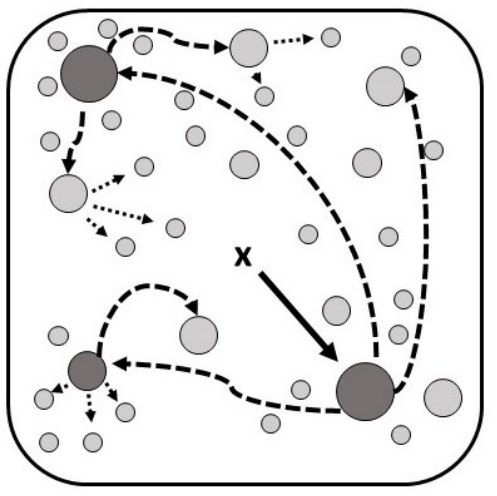

(c)

Note: (a) Expansion diffusion; (b) Relocation diffusion; (c) Hierarchical diffusion; The " $x$ " symbolizes the original source of diffusion and the circles symbolize population settlements; larger circles represent larger settlements, and bold circles represent infected settlements.

Source: This figure was prepared based on Anthamatten and Hazen (2011: 44)

Spread of viruses outward from a source is called expansion diffusion. Diseases, such as COVID-19, as well as simple head lice, that spread by direct transmission are referred to as

${ }^{6}$ COVID-19 is not unique in one respect in that about 30 deadly diseases have been identified since the 1980s (Walters, 2003). If we also consider the new strains of existing diseases, the figures are even higher, whereby 335 infectious diseases emerged between 1940 and 2004 (Jones et al., 2008). HIV-1 and SARS are considered to be completely new to human populations (Anthamatten and Hazen, 2011: 41). 


\section{Spread of Coronavirus and Human Mobility}

contagious diffusion. On the other hand, with relocation diffusion, a virus is introduced to a location outside its original range, this often coming with migration, which moves specific cultural practices as well as diseases. A historical example is the introduction of smallpox to the Americas by the conquistadors, whilst a more recent one is the epidemic of cholera that affected Latin America in 1991. This was thought to have been initiated by the release of the cholera pathogen in Peru by a ship arriving from Asia (Mayer, 2000; Anthamatten and Hazen, 2011: 42). It is clear that in the era of super-mobility and ubiquitous connectedness ${ }^{7}$, air travel carries pathogens rapidly across the globe (Anthamatten and Hazen, 2011: 42). This was the case in 2003 when SARS quickly spread via air passengers around the world. Pathogens and vectors can be transported rapidly with travel and also by transported goods (Masterton and Green, 1991; Anthamatten and Hazen, 2011: 42). For instance, outbreaks of food poisoning have been traced to shipments of food arriving from abroad. Ho et al., (2002) stated that since 1995, several US outbreaks of cyclosporiasis have been connected to raspberries imported from Guatemala (Anthamatten and Hazen, 2011: 44).

Hierarchical diffusion assumes a spatial hierarchy in the spreading of things. In particular, large metropolitan areas see a much speedier spread of diseases compared to small villages. This is simply due to the sheer number of people and goods travelling in and out of such large settlement areas. Due to population density, among other features, proliferation of diseases in cities is faster as people interact with each other in many public spaces (Anthamatten and Hazen, 2011: 45). The early diffusion of Acquired Immune Deficiency Syndrome (AIDS) in the US is an example of hierarchical diffusion. It had started in a few large cities at first, but over a decade it had spread beyond, first to other cities and then to smaller towns. The spread of HIV in Sub-Saharan Africa saw a very similar pattern ${ }^{8}$ (Gould, 1993; Anthamatten and Hazen, 2011: 45).

\section{Data and Method}

The chronology of reporting of the COVID-19 cases is important for our analysis. It was first the case that undiagnosed cases marked by pneumonia in people associated with a seafood market appeared in Wuhan, Hubei Province, China, which were reported on 31 December 2019 (e.g. Holshue et al., 2020). Chinese authorities ${ }^{9}$ reported this cluster of cases and confirmed the coronavirus for the first time on 11 January 2020 in the Wuhan Municipal Health and Health Commission's Report on Unexplained Viral Pneumonia (NHCPRC, 2020a, 2020b). A local doctor in Wuhan had apparently been alerting others to the potential coronavirus cases as early as midDecember 2019. The development of the symptoms for the COVID-19 seemingly confirms such a start date (Chan et al., 2020). The earliest date for spotting the first COVID-19 case appears as being 17 November 2019, although it was not recognised as such at that time (Ma, 2020) and inadvertently, it was carried to other countries (Lipsitch et al., 2020). This means all countries were exposed to the unchecked spread of the virus between up until mid-January in the case of China, whilst laggard countries failed to take any action until the middle March (e.g. Turkey). Hence, millions of more interactions took place, including trips to and from China and other connected destinations until social distancing and other stricter measures were put in place.

The first case in the USA was diagnosed on 19 January 2020, and the first in Italy was diagnosed on 31 January 2020. For many other countries, reports of the first cases came much later.

\footnotetext{
${ }^{7}$ For connectedness and connected consumers, see Sirkeci (2013).

${ }^{8} \mathrm{HIV} / \mathrm{AIDS}$ rates in rural areas of Ghana were higher than those in urban areas throughout the course of its epidemic (Oppong, 1998; Anthamatten and Hazen, 2011: 45).

${ }^{9}$ Information comes from the official website of the National Health and Health Commission in the People's Republic of China.
} 
For example, Turkey announced the first case on 11 March 2020 (McKernan, 2020). In these countries, the number of cases has been rapidly rising since soon after the first one were reported ${ }^{10}$, which means the virus has been spreading unchecked for a lengthy period. It has been well documented that, without measures preventing spread, the number of infected people will increase much more rapidly than were this not the case. The United Kingdom has been one of the laggard countries, where practically no measures were in place until early March against the spread of COVID-19 (Hunter, 2020).

In our exploration of the spread of the disease, some assumptions were formulated. First, we assumed a normal distribution of the cases diagnosed in Wuhan, Hubei, China. We have calculated the crude rate for COVID-19 cases in Hubei province by dividing the number of cases recorded by the total population and each resident in the province is assumed to have had an equal chance of being infected by this virus. This leads to the second assumption: the same crude rate of COVID19 spread (CRS) is true for the people who have travelled from Wuhan. Accordingly, we have estimated the CRS for Hubei province, as abovementioned, the region of the origin, in China. The CRS for the province is estimated to be 1.14 per thousand through the formula (1) [i.e. the number of diagnosed cases (c) divided by the total population (p)]:

$$
C R S=c / p \times 1000
$$

This gives us a probable number of people infected who travelled abroad. These numbers of infected travellers are pro-rata distributed to destination countries, according to the volume of travel to each destination. This is the number of infected people that arrived in each country, which should be treated as the minimum number of cases for each destination at the beginning of the pandemic.

We first established the correlation (see Table 1c, Appendix) between migration data and Wuhan's air travel data, as the latter was not available for all countries, to understand the link between human mobility and the spread of COVID-19. We used the 2017 data on immigrant stock in all countries (WB, 2020) as an indicator of travel intensity between countries. In addition, we included some other contextual indicators that may have been moderating the relationship between these independent variables and the dependant variable (i.e. the number of cases of COVID-19 reported by World Health Organisation - WHO). We tested the Gross National Income (GNI) and Human Development Index (HDI) as potential indicators of the macro environment and decided to use HDI as it reflects a much more holistic picture of individual countries. Population size and population density alongside median age were included in our analyses as moderating demographic variables. We also used the Cato Institute's Human Freedom Score (HFS) (CATO, 2020) to control for the possibility of some countries not accurately reporting the COVID-19 cases and related death statistics. We created cross-tabulations summarising the number of cases, the number of deaths according to the WHO (2020a,b,c), airline travellers volumes from Lai et al. (2020b: 15) and Chinese migrant stock from WB (2020) in top 30 destination countries along with the probable number of cases in these destinations using the CRS (Tables 1a and 1b, Appendix).

Methodologically, firstly we used correlation analysis to understand the relationship between the number of COVID-19 cases of infection and death as well as potential moderating factors, where the focus is on human mobility drivers (Table 1c, Appendix). Secondly, we ran multivariate regression models to understand the determinants of the number of COVID-19 cases by country.

\footnotetext{
${ }^{10}$ For earlier analyses of such a development, see: https://freelonia.org/coronavirus-italian-job/ and https://freelonia.org/gec-kalanulkelerde-vaka-sayisi-hizla-artiyor/
}

Copyright @ 2020 MIGRATION LETTERS 


\section{Spread of Coronavirus and Human Mobility}

This can also offer a basis for developing a predictive model. Thirdly, we used cluster analysis in order to determine the spatial clustering with the exploratory data from the selected 111 countries $^{11}$. The above described analyses were carried out using the IBM PASW Statistics (Predictive Analytics Software Statistics) program. Cluster analysis was calculated using the k-means algorithm ${ }^{12}$. Cluster analysis is one of the most widely used methods of statistical analysis in social sciences (Rencher, 2002). It considers the similarities of individuals, objects, or spatial units (countries in this study) and groups them into two or more sub-groups (Everitt and Dunn, 1991; Afifi and Clark, 1999; Rencher, 2002; Addio and Ercole, 2005; Yüceşahin and Tulga, 2017). The analysis indicates the spatial units (countries) assigned to the same cluster that are similar in terms of the values of the variables.

\section{Findings and Discussion}

We, first, examined the patterns of COVID-19 spread around the world and identified four clusters of countries reflecting their profiles and the volume of cases and deaths along with some key macro indicators as moderating factors. We explored the global data and what has been reported by individual countries and tried to understand the patterns in relation to immigrant stocks from China along with other contextual factors. The following equations were used in the three multivariate regression models run to assess the relative importance of different factors in explaining the total number of COVID-19 cases (TCC), i.e. our dependent variable (Table 1 and 2):

$$
\begin{gathered}
\hat{y}=\beta_{0}(\text { constant })+\beta_{1}(\mathrm{TPO})+\beta_{2}(\mathrm{POD})+\beta_{3}(\mathrm{MEA})+\beta_{4}(\mathrm{HDI})+\beta_{5}(\mathrm{HFS})+\beta_{6}(\mathrm{ISFC})+\mathcal{E} \quad \text { (Model 1) } \\
\hat{\mathrm{y}}=2.313+1.678+8.258+0.026+4.951+0.048+6.852+0.523
\end{gathered}
$$$$
\hat{\mathrm{y}}=\beta_{0}(\mathrm{constant})+\beta_{1}(\mathrm{TPO})+\beta_{2}(\mathrm{POD})+\beta_{3}(\mathrm{MEA})+\beta_{4}(\mathrm{HDI})+\beta_{5}(\mathrm{HFS})+\beta_{6}(\mathrm{ISIC})+\varepsilon \quad(\text { Model } 2)
$$$$
\hat{\mathrm{y}}=2.543+1.637+6.477+0.023+5.094+0.018+6.725+0.499
$$$$
\hat{y}=\beta_{0}(\text { constant })+\beta_{1}(\mathrm{TPO})+\beta_{2}(\mathrm{POD})+\beta_{3}(\mathrm{MEA})+\beta_{4}(\mathrm{HDI})+\beta_{5}(\mathrm{HFS})+\beta_{6}(\mathrm{HMO})+\varepsilon \text { (Model 3) }
$$$$
\hat{\mathrm{y}}=2.454+1.765+5.827+0.025+5.112+0.035+6.517+0.517
$$

Moderating variables in the regression models included total population (TPO), population density (POD), median age (MEA), HDI, HFS, immigrant stock from China (ISFC), immigrant stock in China (ISIC) and human mobility ${ }^{13}$ (HMO). The correlation matrix (Table 1) confirms that all the independent variables, except for the TPO and POD, are significantly correlated with the $\mathrm{TCC}^{14}$. However, there are some collinearity problems between the MEA and HDI; the GNI and HDI; and the ISFC and HMO. The correlation coefficient (r) between the MEA and HDI is 0.876;

\footnotetext{
${ }^{11}$ The selection of 111 countries was data driven, whereby we dropped countries where immigrant stock and/or Covid-19 case statistics were not available.

${ }^{12}$ For the details of and justifications for K-means clustering, please see Afifi and Clark (1999: 395); Bacher (2002: 105); and Rencher (2002: 482).

${ }^{13}$ In order to represent the size of international human mobility, this variable is obtained by multiplying ISFC by ISIC.

${ }^{14}$ We transformed and used logarithmic equivalents (i.e. $\log _{10}$ TCC ) of the number of cases in the dependent variable, TCC.
} 
between the GNI and HDI is 0.837 and between the ISFC and HMO is 0.838 . To explore the differences and delineate the relationship, three different models were run, as shown in Table 2.

Table 1. Correlation matrix for the exploratory multiple regression analyses $(\mathrm{n}=111)$

\begin{tabular}{|c|c|c|c|c|c|c|c|c|c|}
\hline & TPO & POD & MEA & HDI & GNI & HFS & ISFC & ISIC & $\mathrm{HMO}$ \\
\hline Total COVID-19 cases (TCC) & 0.177 & 0.064 & $-0.714^{* *}$ & $-0.761^{* *}$ & $-0.664^{* *}$ & $-0.561^{* *}$ & $0.375^{* *}$ & $0.313^{* *}$ & $0.297^{* *}$ \\
\hline Total Population (TPO) & 1 & 0.018 & -0.056 & -0.087 & -0.081 & -0.106 & $0.192^{*}$ & $0.213^{*}$ & 0.161 \\
\hline Population density (POD) & & 1 & -0.124 & -0.126 & $-0.323^{* *}$ & -0.097 & 0.160 & 0.052 & 0.034 \\
\hline Median age (MEA) & & & -1 & $-0.876^{* *}$ & $-0.698^{* *}$ & $-0.713^{* *}$ & $0.227^{*}$ & 0.124 & 0.170 \\
\hline Human Development Index (HDI) & & & & -1 & $-0.837^{* *}$ & $-0.751^{* *}$ & $0.270^{* *}$ & 0.116 & $0.190^{*}$ \\
\hline Gross National Income (GNI) & & & & & -1 & $-0.660^{* *}$ & $0.352^{* *}$ & 0.086 & $0.226^{*}$ \\
\hline Human Freedom Score (HFS) & & & & & & -1 & $0.261^{* *}$ & 0.069 & 0.184 \\
\hline Immigrant stock from China (ISFC) & & & & & & & 1 & $0.456^{* *}$ & $0.838^{* *}$ \\
\hline Immigrant stock in China (ISIC) & & & & & & & & 1 & $0.708^{* *}$ \\
\hline Human mobility (HMO) & & & & & & & & & 1 \\
\hline
\end{tabular}

Regression results confirmed that the total number of cases for each country is significantly moderated by the factors included in our model. In Model 1, the TPO, POD, MEA, HDI, HFS, and ISFC explain $65 \%$ of the variance in the number of COVID-19 cases in each county. In this model, in which the ISIC and HMO are excluded because of the high-level correlation among them, both the TPO and HDI are the most significant factors affecting the TCCs. Despite the high-level of correlation between MEA and HDI, we included these two variables in the model since they are conceptually quite different indicators. At the same time, the volume of immigrant stock in destination countries (ISFC) is a statistically significant indicator for the volume of COVID-19 cases (TCCs).

Despite there being no collinearity problem between ISFC and ISIC, we used these indicators in the models 1 and 2 in order to present their explanatory power separately. Similar to the first model, the five variables (TPO, POD, MEA, HDI, HFS, and ISIC) were significant in determining the number of COVID- 19 cases and the model 2 also explains $66 \%$ of the variance, with HDI being the most significant factor. Moreover, TPO and ISIC are the significant factors in Model 2. Confirming the role of ISIC and ISFC in these two models support our argument that human mobility is a significant determinant of the spread and volume of COVID-19 cases (TCCs) across the world. Therefore, in the third model, instead of ISFC and ISIC, we have included an interaction of the two, i.e. Human mobility (HMO) along with other contextual variables, namely TPO, POD, MEA, HDI, and HFS. These included independent variables explain $64 \%$ of the variance in TCCs in each country. The TPO and HDI are the most important indicators for the TCCs. Moreover, human mobility is a statistically significant factor for the TCCs in the countries.

Considering the spread of COVID-19 among 110 countries, for the three models we can argue that countries with larger populations, and higher HDI scores have the highest COVID-19-case levels. Some of these factors are probably more or less self-explanatory. For example, population size is directly related to the pool size for potentially infected individuals. HDI is significant and it shows that relatively poor countries will be affected worse from the COVID-19 pandemic. However, we found no significant relationships between the TCC and population density (POD) and HFS. These results tell us that every one unit increase in the HDI score may mean about five more COVID-19 cases being reported according to these models. In all three models, a one person increase in population size indicates over 1.6 more COVID-19 cases. HFI scores were found to be 
insignificant in determining the number of cases reported, thus not supporting the negative relationship that was expected.

Table 2. Results of multiple regressions for the dependent variable TCCs by country $\left(n=110^{b}\right)$

\begin{tabular}{|c|c|c|c|c|c|c|}
\hline \multirow{2}{*}{ Variable $^{\mathrm{s}}$} & \multicolumn{2}{|c|}{ Model 1} & \multicolumn{2}{|c|}{ Model 2} & \multicolumn{2}{|c|}{ Model 3} \\
\hline & $\beta$ coefficient & $\mathrm{t}$-value & $\beta$ coefficient & $\mathrm{t}$-value & $\beta$ coefficient & $\mathrm{t}$-value \\
\hline (Constant) & -2.313 & $-4.423 * * *$ & -2.543 & $-5.094 * * *$ & -2.454 & $-4.747 * * *$ \\
\hline $\begin{array}{l}\text { Total Population } \\
\text { (TPO) }\end{array}$ & $1.678 \mathrm{E}-09$ & $3.529 * *$ & $1.637 \mathrm{E}-09$ & $3.492 * *$ & $1.765 \mathrm{E}-09$ & $3.720 * * *$ \\
\hline $\begin{array}{l}\text { Population density } \\
\text { (POD) }\end{array}$ & $-8.258 \mathrm{E}-05$ & -1.028 & $-6.477 \mathrm{E}-05$ & -0.823 & $-5.827 \mathrm{E}-05$ & -0.726 \\
\hline $\begin{array}{l}\text { Median age } \\
\text { (MEA) }\end{array}$ & 0.026 & 1.709 & 0.023 & 1.525 & 0.025 & 1.588 \\
\hline $\begin{array}{l}\text { Human } \\
\text { development index } \\
\text { (HDI) }\end{array}$ & 4.951 & $4.652 * * *$ & 5.094 & $4.876^{* * *}$ & 5.112 & $4.791 * * *$ \\
\hline $\begin{array}{l}\text { Human freedom } \\
\text { score (HFS) }\end{array}$ & -0.048 & -0.501 & -0.018 & -0.196 & -0.035 & -0.373 \\
\hline $\begin{array}{l}\text { Immigrant stock } \\
\text { from China (ISFC) }\end{array}$ & $6.852 \mathrm{E}-07$ & $2.383^{*}$ & - & - & - & - \\
\hline $\begin{array}{l}\text { Immigrant stock in } \\
\text { China (ISIC) }\end{array}$ & - & - & $6.725 \mathrm{E}-06$ & $2.909 * *$ & - & - \\
\hline $\begin{array}{l}\text { Human mobility } \\
\text { (HMO) }\end{array}$ & - & - & - & - & $6.517 \mathrm{E}-12$ & $2.004 *$ \\
\hline $\begin{array}{l}\text { Adjusted } R^{2} \\
F\end{array}$ & \multicolumn{2}{|c|}{$\begin{array}{c}0.65 \\
34.205\end{array}$} & \multicolumn{2}{|c|}{$\begin{array}{c}0.66 \\
35.519\end{array}$} & \multicolumn{2}{|c|}{$\begin{array}{c}0.64 \\
33.419\end{array}$} \\
\hline
\end{tabular}

Source: Data from ECDC (2020); UN (2019, 2020); WB (2020); Vásquez and Porčnik (2019), authors' calculations.

Significance: $* * * p<0.001 ; * * p<0.01 ; * p<0.05$.

${ }^{a}$ For further information on some of the variables by countries, see Table $2 \mathrm{a}, \mathrm{b}, \mathrm{c}$, and $\mathrm{d}$ in the Appendix.

${ }^{b}$ Although Myanmar is involved in the Covid-19 case and death list, obtained from ECDC (2020), the case and the death cells have zero. Therefore, the regression analyses omitted this country during the analysing processes. In addition, China is excluded from both the data (Table 2a, b, c, and d in the Appendix) and analyses since this country does not have (Chinese) any migrant stock.

We have tested the role of migration in three models. In model 1 , we have shown that every additional immigrant from China (ISFC) in a given destination country indicates a 6.9 increase in the number of COVID-19 cases. In model 2, every additional immigrant in China (ISIC) from a destination country means 6.73 more COVID-19 cases being found in that country. In model 3, we have used an interaction variable (product of ISFC and ISIC) to show that every one unit increase in HMO leads to 6.52 more COVID-19 cases. Thus, we argue it is not the number of Chinese immigrants, but rather, the totality of human mobility in both directions, i.e. including immigrants in China, that matters.

The volume of migration in each migration corridor linking the countries of origin and destination appears as a strong indicator for the spread of the pandemic. This can be an important proxy to see how countries can predict the scale of and prepare for a pandemic. The role of migration is also explain why similarly large and developed countries have varying numbers of cases emerging. Using migration data alongside the other indicators we have used in the analyses may be helpful for organising the global response to similar pandemics in terms of where to concentrate the resources at early stages so as to contain the spread. This relates to our next question. We discuss in the following passages which countries are more vulnerable and which are more resistant. 
We have determined the spatial clustering (i.e. similarities and disparities) of the selected countries using the total number of COVID-19 cases (WHO, 2020a, b, c and ECDC, 2020) ${ }^{15}$ along with other all contextual variables. The data for the chosen 10 variables have different units for the 111 focal countries and thus, all have been analysed after logarithmic transformation ${ }^{16}$. As a result of the cluster analysis, the values in log format averages (final cluster centres) of the variables are presented in Table 3. Accordingly, we have assigned 51 of the 111 countries to cluster $1 ; 35$ countries to cluster $2 ; 15$ countries to cluster 3 , and 10 countries to cluster 4 . The values in log format in Table 3 have been converted into a plot diagram to illustrate clearly the differences between the clusters and the countries in each (Figure 2).

The cluster analysis has shown certain spatial and perhaps socioeconomic patterns across the world. The first cluster (1) is marked by relatively low numbers of COVID-19 cases (Table 3 and Figure 2). In this cluster, total deaths, total population, population density, median age, human development index, gross national income, human freedom score, immigrant stock from China, and immigrant stock in China are also slightly lower than for the countries in other clusters. Most of these countries, if not all, are also considered to be low-income countries, with few exceptions, such as Malta and Brunei Darussalam.

Table 3. Final cluster centres obtained from the cluster analysis $(n=111)$

\begin{tabular}{llcccccccccc}
\hline & & \multicolumn{10}{c}{ Variables $^{\mathrm{a}}$} \\
\cline { 3 - 11 } & & TCC & TDE & TPO & POD & MEA & HDI & GNI & HFS & ISFC & ISIC \\
& Cluster 1 & 1.21 & 0.02 & 6.61 & 1.72 & 1.44 & -0.17 & 3.92 & 0.84 & 2.84 & 2.48 \\
$\log _{10}$ & Cluster 2 & 2.60 & 0.67 & 7.17 & 1.88 & 1.54 & -0.09 & 4.32 & 0.85 & 3.72 & 3.01 \\
& Cluster 3 & 2.67 & 0.98 & 7.86 & 2.02 & 1.54 & -0.11 & 4.24 & 0.85 & 4.95 & 4.36 \\
& Cluster 4 & 4.11 & 2.49 & 7.65 & 2.31 & 1.63 & -0.04 & 4.64 & 0.92 & 5.16 & 3.98 \\
\hline \multirow{2}{*}{ Anova Test } & F Value & 78.39 & 63.82 & 22.29 & 2.88 & 12.02 & 15.17 & 14.20 & 4.84 & 77.17 & 60.92 \\
& $\mathrm{P}$ & $* * *$ & $* * *$ & $* * *$ & $*$ & $* * *$ & $* * *$ & $* * *$ & $* *$ & $* * *$ & $* * *$ \\
\hline
\end{tabular}

Source: Data from ECDC (2020); UN (2019, 2020); WB (2020); Vásquez and Porčnik (2019), with authors' calculations

${ }^{a}$ TCC: Total COVID-19 cases; $\quad$ TDE: Total COVID-19 related deaths; TPO: Total population; POD:

Population density; MEA: Median age; HDI: Human Development Index; GNI: Gross National Income; HFS: Human

Freedom Score; ISFC: Immigrant Stock from China; ISIC: Immigrant Stock in China.

Significance: $* * * p<0.001 ; * * p<0.01 ; * p<0.05$

In cluster 2, all the indicators are higher than with the first cluster, whereas the gross national income is higher than for cluster 3; median age is equal to that of cluster 3; and immigrant stock from China and immigrant stock in China from the origin countries are lower than for cluster 3.

In cluster 3, total COVID-19 cases is higher than for cluster 1 and 2 . The countries in cluster 3 have higher deaths, population density, median age, immigrant stock from China and immigrant stock in China compared to the countries in the first two clusters. In cluster 3, the total population and immigrant stock in China are higher than the two other clusters. In addition, median age and HFS are equal to cluster 2. In this cluster, 8 countries are located in South and East Asia along with Australia, Canada, New Zealand and Brazil and Russia, two emerging economies.

\footnotetext{
${ }^{15}$ The total number of COVID-19 cases by country is presented in Tables $2 \mathrm{a}, \mathrm{b}, \mathrm{c}$, and $\mathrm{d}$ in the Appendix.

${ }^{16}$ Logarithmic transformation is a method of standardising data values in $\log \left(\log _{10}\right)$ format. Cluster analysis is a sensitive analysis for large variables, which can lead to incorrect results because the analysis tries to parse large sets of values. For this reason, the variables to be used in the analysis must either be the same (for example, all percentages) or transformed. Since the units of the variables used in the analysis differ from each other (numbers, years, rates, percentages, scores etc.), they have been standardised and transformed into $\log \left(\log _{10}\right)$ format. A large $\log _{10}$ value shows that the variable is high in terms of the rate, speed, or score, while a small $\log _{10}$ value shows that they are low.
} 
Figure 2. Clustering of countries and the final cluster centres of the variables

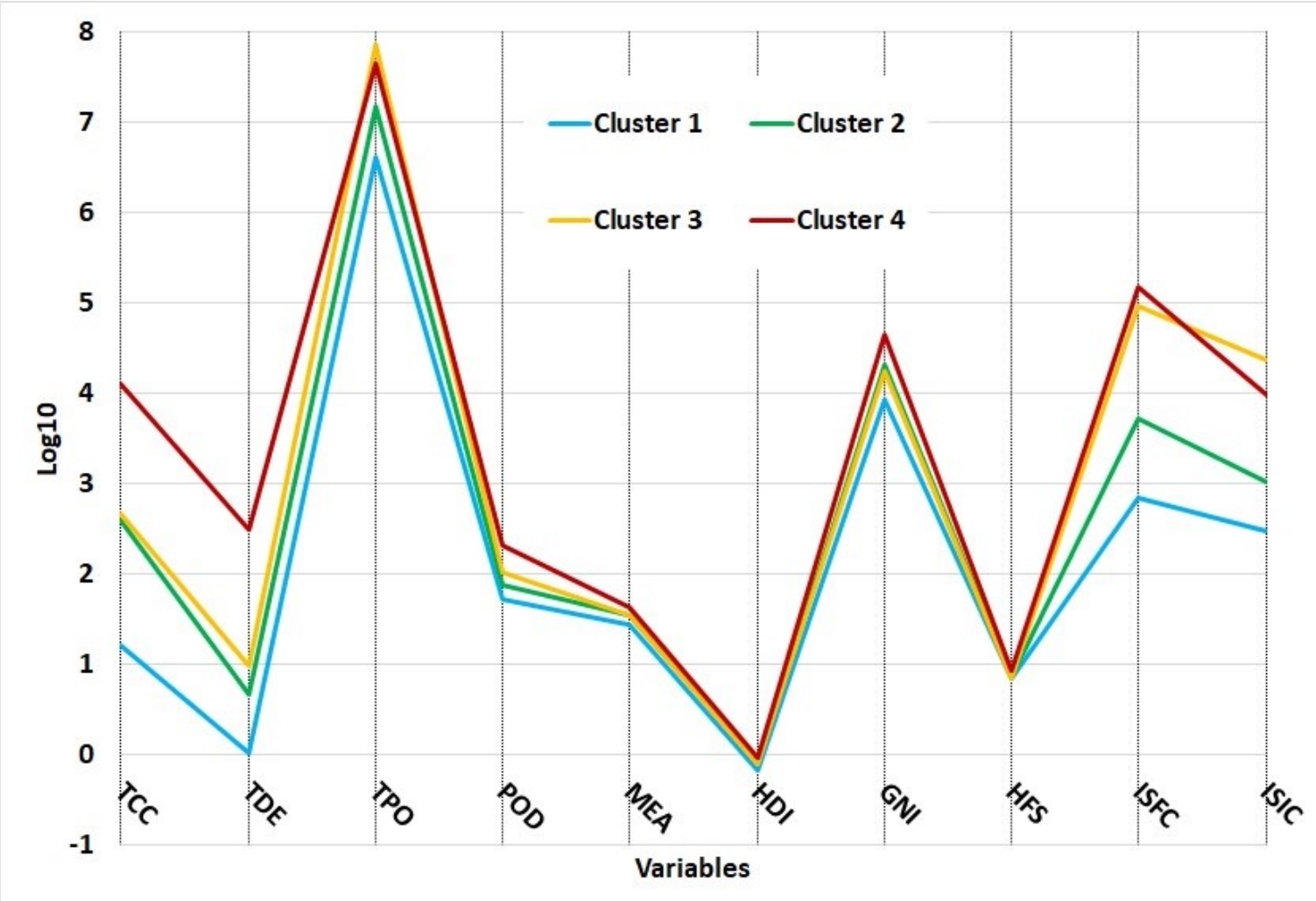

\begin{tabular}{|c|c|c|c|}
\hline Cluster 1 & Cluster 2 & Cluster 3 & Cluster 4 \\
Azerbaijan, Bahamas, Barbados, Bhutan, & Argentina, Algeria, & Australia, & Belgium, \\
Bolivia, Bosnia and Herzegovina, & Austria, Bulgaria, Chile, & Bangladesh, & France, \\
Brunei Darussalam, Cambodia, Central & Costa Rica, Czechia, & Brazil, Canada, & Germany, \\
African Republic, Congo, Croatia, & Denmark, Dominican & India, Indonesia, & Italy, the \\
Cyprus, El Salvador, Estonia, Fiji, & Republic, Ecuador, & Japan, Malaysia, & Netherlands, \\
Gabon, Georgia, Ghana, Guatemala, & Egypt, Finland, Greece, & Myanmar, New & South \\
Guinea, Guyana, Haiti, Honduras, & Hungary, Ireland, Israel, & Zealand, & Korea, \\
Iceland, Kenya, Kyrgyzstan, Latvia, & Jordan, Kazakhstan, & Philippines, & Spain, \\
Lithuania, Madagascar, Malta, & Lebanon, Luxembourg, & Russia, & Switzerland, \\
Mauritania, Mauritius, Moldova, & Mexico, Norway, & Singapore, & the UK, and \\
Mongolia, Namibia, Nepal, Papua New & Pakistan, Panama, Peru, & Thailand, and & the USA \\
Guinea, Paraguay, Rwanda, Serbia, & Poland, Portugal, & Vietnam & \\
Seychelles, Slovakia, Sudan, Suriname, & Romania, Slovenia, & & \\
Timor Leste, Togo, Trinidad and Tobago, & South Africa, Sri Lanka, & & \\
Uganda, Uruguay, Tanzania, and Zambia & Sweden, Turkey, & & \\
& Ukraine, and Venezuela & & \\
& & \\
\hline
\end{tabular}

Note: This plot diagram was prepared by the final cluster centres obtained from the cluster analysis (see Table 3).

Explanation: TCC: Total COVID-19 cases; TDE: Total COVID-19 related deaths; TPO: Total population; POD: Population density; MEA: Median age; HDI: Human Development Index; GNI: Gross National Income; HFS: Human Freedom Score; ISFC: Immigrant Stock from China; ISIC: Immigrant Stock in China. 
Cluster 4 comprises the USA, Belgium, Germany, Italy, the Netherlands, the UK, Switzerland, Spain, France, and South Korea, all high-income countries with strong health infrastructures. In this cluster total population is as high as in cluster 3. These countries are marked by a remarkably high volume of COVID-19 cases and large diasporas from China as well as higher population density compared to the other clusters. Remarkably, in this cluster, immigrant stock in China from the other countries is lower than for Cluster 3.

The $\mathrm{F}$ values in the cluster analysis show that the most important variables contributing to the clustering regarding the countries' convergence or divergence are, respectively, the total COVID19 cases (78.39), immigrant stock from China (77.17), total deaths (63.82), immigrant stock in China (60.92), total population (22.29), HDI (15.17), GNI (14.20), HFS (4.84), and population density (2.88) (Table 3 ). The top four most important variables contributing to this clustering are the total COVID-19 cases (TCC) $(\mathrm{F}=78.39)$, immigrant stock from China $(\mathrm{F}=77.17)$, total deaths $(\mathrm{F}=63.82)$, and immigrant stock in China $(\mathrm{F}=60.92)$. As can be seen from the red line in Figure 2, ten countries in cluster 4 are in relocation areas of the spatial diffusion pattern of COVID-19. These ten countries are located in three regions: (1) origin-region (China and a neighbouring country, South Korea); (2) first relocation-region (Western Europe); and (3) second relocation-region (USA).

It is important to note that we are examining the predicting power of immigrant populations/diasporas from China and immigrants/diasporas in China for understanding the spread (and volume) of COVID-19 cases, also being in line with the diffusion theories explained at the beginning. However, we are not making a causal relationship, but rather, identifying a proxy to understand the diffusion. Migration relationships or corridors of human mobility established over time as cultures of migration emerge are indicators of developing social and economic relationships between the countries involved. This means more investment and more remittance flows, more holiday trips, and a significant growth regarding other relationships.

\section{Conclusion}

The spread of COVID-19 seems to follow a relocation diffusion pattern beyond the neighbouring countries. A hierarchical diffusion pattern was also observed regarding many countries in cluster 4 we have identified. These countries marked by high HDI scores, relatively large populations, high income and sizeable Chinese diasporas have seen the largest volumes of infected populations. However, there was also evidence confirming an expansion to neighbouring countries, as expected, towards Japan and South Korea and other South-East Asian neighbours where initially a significant number of cases were reported.

The statistical models that we have applied clearly show that the COVID-19 spread around the world could have been estimated and mapped out to a substantial degree of accuracy by simply taking into account some macro variables, such as the population size, HDI scores, and immigrant stock from the origin at each destination. We have applied the statistical model at the country level. However, where data are available, this model can be used to identify certain regional or local level concentration of infected individuals. It emerges from the most recent data that large metropolitan areas and global cities, such as London and New York, are taking the lion share of cases in their respective countries. Therefore, further spread from these centres could also be examined using a similar approach. What matters in this model is that viruses relocate to surrounding areas or beyond by transport following the diffusion theory we presented at the beginning of this work. 


\section{Spread of Coronavirus and Human Mobility}

Our analyses of the data available show that governments around the world could have been more proactive and prepared in responding to the COVID-19 pandemic, if they had utilised model(s) like the one suggested in this article. So far, late and reactionary responses to the crisis have seemingly led to sharp increases in the number of cases and deaths in many countries. We argue that this could have been avoided, if travel data had been used during the early stages of diffusion. By monitoring immigrant stock data and/or travel volume data based on human mobility corridors (i.e. origins and destinations), countries could have been better prepared to tackle the spread of COVID-19. This is one of the lessons that should be learnt for tackling future pandemics more effectively than the present one.

Another important note is that despite some racist exchanges by politicians in early phases of the COVID-19 crisis, the spread of the virus does not have an ethnic origin. We have shown the role of human mobility patterns irrespective of ethnic or national origins. Many other studies by scientists also point that the origin of the viruses have not been confirmed. Given the fact that human settlements more and more expand into living spaces of animals, there is likely to be more transfer of such viruses from animals to humans. Focusing on this latter challenge may mean better use of our resources and energy for future generations.

\section{References}

Afifi, A.A. \& Clark, V. (1999). Computer-Aided Multivariate Analysis. Third ed., London: Chapman and Hall/CRC Press.

Addio, A.C. \& Ercole, M.M. (2005). Trends and determinants of fertility in OECD countries: The role of policies. Directorate for Employment, Labour and Social Affairs, OECD Social, Employment and Migration Working Papers, no. 27. Cedex.

Anthamatten, P. \& Hazen, H. (2011). An Introduction to the Geography of Health. London: Routledge Taylor \& Francis Group.

Bacher, J. (2002). Cluster Analysis. Nuremberg: University Erlangen.

CATO (Cato Institute) (2020). Human Freedom Index by Cato Institute. Available at: https://object.cato.org/sites/ cato.org/files/human-freedom-index-files/human-freedom-index-2019.xlsx Accessed: 11/03/2020.

Chan, J. F. W., Yuan, S., Kok, K-H., To, K. K-W., Chu, H., Yang, J., Xing, F., Jieling Liu, BNurs, J. L., Yip, C. C-Y., Rosana Wing-Shan Poon, R. W-S., Tsoi, H-W., Lo, S. K-F., Chan, K-H., Poon, V. K-M., Chan, W-M., Ip, J. D., Cai, J-P., Vincent Chi-Chung Cheng, V. C-C., Chen, H., Christopher Kim-Ming Hui, C. K-M. and Prof Kwok-Yung Yuen, K-Y. (2020). A familial cluster of pneumonia associated with the 2019 novel coronavirus indicating person-to-person transmission: a study of a family cluster. The Lancet, 395(10223): 514-523.

Cohen, J. H. (2004). The Culture of Migration in Southern Mexico. Austin, TX: University of Texas Press.

Cohen, J. H., \& Sirkeci, I. (2011). Cultures of migration: The global nature of contemporary mobility. Austin, TX: University of Texas Press.

ECDC (European Centre for Disease Prevention and Control) (2020). COVID-19 Geographic Distribution Worldwide. Accessed from https://www.ecdc.europa.eu/sites/default/files/documents/COVID-19-geographic-disbtributionworldwide-2020-03-23.xlsx, on March 23, 2020.

Everitt, B. S. \& Dunn, G. (1991). Applied Multivariate Data Analysis. London: Cambridge University Press.

Ferguson, N. M., Laydon, D., Nedjati-Gilani, G., Imai, N., Ainslie, K., Baguelin, M., Bhatia, S., Boonyasiri, A., Cucunubá, Z., Cuomo-Dannenburg, G., Dighe, A., Dorigatti, I., Fu, H., Gaythorpe, K., Green, W., Hamlet, A., Hinsley, W., Okell, L. C., van Elsland, S., Thompson, H., Verity, R., Volz, E., Wang, H., Wang, Y., Walker, P. G. T., Walters, C., Winskill, P., Whittaker, C., Donnelly, C. A., Riley, S., Ghani, A.C. (2020). Impact of non-pharmaceutical interventions (NPIs) to reduce COVID-19 mortality and healthcare demand. Imperial College COVID-19 Response Team. DOI: https://doi.org/10.25561/77482. Accessed from https://www.imperial.ac.uk/media/imperialcollege/medicine/sph/ide/gida-fellowships/Imperial-College-COVID19-NPI-modelling-16-032020.pdf, on March 20, 2020.

Gould, P. (1993). The Slow Plague: A Geography of the AIDS Pandemic. Oxford: Blackwell Publishers. 
Ho, A. Lopez, A. Eberhart, M., Levenson, R., Finkel, B. da Silva, A., Roberts, J., Orlandi, P., Johnson, C. and Herwaldt, B. (2002). Outbreak of cyclosporiasis associated with imported raspberries, Philadelphia, Pennsylvania, 2000. Emerging Infectious Diseases, 8: 783-788.

Holshue, M. L., DeBolt, C., Lindquist, S., Lofy, K. H., Wiesman, J., Bruce, H., Spitters, C., Ericson, K., Wilkerson, S., Tural, A., Diaz, G., Cohn, A., Fox, C. L., Patel, A., Gerber, S. I., Kim, L., Tong, S., Lu, X., Lindstrom, S., Pallansch, M. A., Weldon, W. C., Biggs, H. M., Uyeki, T. M. and Pillai, S. K. (2020). First case of 2019 novel coronavirus in the United States. The New England Journal of Medicine, 382 (10): 929-936.

Hunter, D.J. (2020). Covid-19 and the Stiff Upper Lip — The Pandemic Response in the United Kingdom. The New England Journal of Medicine, DOI: 10.1056/NEJMp2005755.

Jilani, T. N., Jamil, R. T., \& Siddiqui, A. H. (2019). H1N1 Influenza (Swine Flu). In StatPearls [Internet]. StatPearls Publishing. Accessed from https://www.ncbi.nlm.nih.gov/books/NBK513241/, on March 22, 2020.

Jones, K., Patel, N., Levy, M. Storeygard, A., Balk, D., Gittleman, J. and Daszak, P. (2008). Global trends in emerging infectious diseases. Nature, 451: 990-993.

Klempner, M. \& Shapiro, D. (2004). Crossing the species barrier - one small step to man, one giant leap to mankind. New England Journal of Medicine, 350: 1171-1172.

Lai, C. C., Shih, T. P., Ko, W. C., Tang, H. J., \& Hsueh, P. R. (2020a). Severe acute respiratory syndrome coronavirus 2 (SARS-CoV-2) and corona virus disease-2019 (COVID-19): the epidemic and the challenges. International journal of antimicrobial agents, 105924. https://doi.org/10.1016/j.ijantimicag.2020.105924. Accessed: 25 March 2020.

Lai, S., Bogoch, I. I., Ruktanonchai, N. W., Watts, A., Lu, X., Yang, W., Yu, H., Khan, K. \& Tatem, A. J. (2020b). Assessing spread risk of Wuhan novel coronavirus within and beyond China, January-April 2020: A travel networkbased modelling study. medRxiv (The Preprint Server for Health Sciences) preprint: 1-25. doi: https://doi.org/10.1101/2020.02.04.20020479, Accessed: March 11, 2020.

Lipsitch, M., Swerdlow, D. L., \& Finelli, L. (2020). Defining the epidemiology of Covid-19-studies needed. New England Journal of Medicine. Accessed from https://www.nejm.org/doi/full/10.1056/NEJMp2002125, on March 22, 2020.

Ma, J. (2020). Coronavirus: China's first confirmed Covid-19 case traced back to November 17, South China Morning Post, 13 March 2020. Accessed from https://www.scmp.com/news/china/society/article/3074991/coronavirus-chinasfirst-confirmed-covid-19-case-traced-back, on March 20, 2020.

MacKernan, B. (2020). Turkey announces its first case of coronavirus. The Guardian, 11 March 2020. Accessed from https:/www.theguardian.com/world/2020/mar/11/turkey-announces-its-first-case-of-coronavirus, on March 16, 2020.

Masterton, R. and Green, A. (1991). Dissemination of human pathogens by airline travel. Journal of Applied Bacteriology (Symposium Supplement), 70: S31-S38.

Mayer, J. (2000). Geography, ecology and emerging infectious diseases. Social Science \& Medicine, 50: $937-952$.

NHCPRC (National Health Commission of People's Republic of China) (2020a). Outbreak Notification. Accessed from http://www.nhc.gov.cn/xcs/yqtb/list_gzbd_3.shtml, on March 16, 2020.

NHCPRC (National Health Commission of People's Republic of China) (2020b). Wuhan Municipal Health and Health Commission's Report on Unexplained Viral Pneumonia. Accessed from http://www.nhc.gov.cn/xcs/yqtb/202001/ 1beb46f061704372b7ca41ef3e682229.shtml, on March 16, 2020.

Oppong, J. (1998). A vulnerability interpretation of the geography of HIV AIDS in Ghana, 1986-1995. Professional Geographer, 50: 437-448.

Rencher, A.C. (2002). Methods of Multivariate Analysis. Second Ed., London: John Wiley \& Sons.

Sirkeci, I. (2013). Transnational Marketing and Transnational Consumers. London: Springer.

United Nations (UN) (2020). The 2019 Revision of World Population Prospects. Accessed from https://population.un. org/wpp/, on March 24, 2020.

United Nations (UN) (2019). Human Development Report 2019: Beyond Income, Beyond Averages, Beyond Today: Inequalities in Human Development in the 21st Century. United Nations Development Programme, New York.

Vásquez, I. and Porčnik, T. (2019). The Human Freedom Index 2019: A Global Measurement of Personal, Civil, and Economic Freedom. Washington: Cato Institute, Fraser Institute, and the Friedrich Naumann Foundation for Freedom.

Walters, M. (2003). Six Modern Plagues and How We are Causing Them. Washington, DC: Island Press / Shearwater Books.

WB (World Bank) (2020). Migration and Remittances Data. Accessed from https://www.worldbank.org/en/topic/ migrationremittancesdiasporaissues/brief/migration-remittances-data, on March 15, 2020.

WHO (World Health Organization) (2020a). Coronavirus. Accessed from https://www.who.int/healthtopics/coronavirus, on March 29, 2020. 
WHO (World Health Organization) (2020b). Coronavirus Disease (Covid-19) Outbreak. Accessed from https://experience.arcgis.com/experience/685d0ace521648f8a5beeeee1b9125cd, on March 11, 2020.

WHO (World Health Organization) (2020c). Coronavirus Disease 2019 (Covid-19) Situation Reports. Accessed from https://www.who.int/emergencies/diseases/novel-coronavirus-2019/situation-reports/, on March 29, 2020.

WHO (World Health Organization) (2020d). Middle East Respiratory Syndrome Coronavirus (MERS-CoV). Accessed from https://www.who.int/emergencies/mers-cov/en/, on March 20, 2020.

WHO (World Health Organization) (2020e). Severe Acute Respiratory Syndrome (SARS). Accessed from https://www.who.int/csr/sars/en/, on March 20, 2020.

WHO (World Health Organization) (2020f). Coronavirus Disease (COVID-19) Pandemic. Accessed from https://www.who.int/emergencies/diseases/novel-coronavirus-2019, on March 20, 2020.

Yüceşahin, M. M. and Tulga, A. Y. (2017). Demographic and Social Change in the Middle East and North Africa: Processes, Spatial Patterns, and Outcomes. Population Horizons, 14(2): 47-60. 


\section{Appendix}

Table 1a. Key indicators for top 30 destination countries receiving air travellers from Wuhan, Hubei Province, China $(\mathrm{n}=30)$

\begin{tabular}{|c|c|c|c|c|c|c|c|}
\hline Country & $\begin{array}{r}\text { Airline travellers' } \\
\text { volume } \\
\text { (in thousand) }\end{array}$ & $\begin{array}{r}\text { Total } \\
\text { Covid- } \\
19 \text { cases }^{*} \\
\end{array}$ & $\begin{array}{r}\text { Total } \\
\text { Covid-19 } \\
\text { deaths } \\
\end{array}$ & $\begin{array}{r}\text { Total } \\
\text { population (in } \\
\text { thousand) }\end{array}$ & $\begin{array}{r}\text { Crude rate of } \\
\text { spread (CRS) per } \\
\text { thousand }\end{array}$ & $\begin{array}{r}\text { Population density } \\
\text { (persons per } \\
\text { square km) } \\
\end{array}$ & $\begin{array}{r}\text { Median } \\
\text { age } \\
\text { (years) } \\
\end{array}$ \\
\hline Thailand & 485.6 & 721 & 1 & 69,626 & 0,0104 & 136.3 & 40.1 \\
\hline Japan & 382.8 & 1,089 & 41 & 126,860 & 0,0086 & 348.0 & 48.4 \\
\hline Hong Kong & 244.4 & 274 & 4 & 7,436 & 0,0368 & $7,082.1$ & 44.8 \\
\hline Taiwan & 237.7 & 165 & 2 & 23,774 & 0,0069 & 671.4 & 42.5 \\
\hline South Korea & 230.2 & 8,961 & 113 & 51,225 & 0,1749 & 526.8 & 43.7 \\
\hline USA & 189.1 & 35,206 & 471 & 329,065 & 0,1070 & 36.0 & 38.3 \\
\hline Malaysia & 150.6 & 1,306 & 10 & 31,950 & 0,0409 & 97.2 & 30.3 \\
\hline Singapore & 138.6 & 455 & 2 & 5,804 & 0,0784 & $8,291.9$ & 42.2 \\
\hline Viet Nam & 115.6 & 118 & 0 & 96,462 & 0,0012 & 311.1 & 32.5 \\
\hline Australia & 109.8 & 1,709 & 7 & 25,203 & 0,0678 & 3.3 & 37.9 \\
\hline Indonesia & 99.6 & 514 & 48 & 270,626 & 0,0019 & 149.4 & 29.7 \\
\hline Cambodia & 64.3 & 86 & 0 & 16,487 & 0,0052 & 93.4 & 25.6 \\
\hline Macao, PRC & 62.3 & 19 & 0 & 640 & 0,0297 & $21,419.6$ & 39.3 \\
\hline Germany & 58.0 & 24,774 & 94 & 83,517 & 0,2966 & 239.6 & 45.7 \\
\hline Philippines & 61.6 & 380 & 25 & 108,117 & 0,0035 & 362.6 & 25.7 \\
\hline UK & 46.7 & 5,683 & 281 & 67,530 & 0,0842 & 279.1 & 40.5 \\
\hline Canada & 50.7 & 1,430 & 18 & 37,411 & 0,0382 & 4.1 & 41.1 \\
\hline Italy & 36.9 & 59,138 & 5,476 & 60,550 & 0,9767 & 205.9 & 47.3 \\
\hline UAE & 38.7 & 153 & 2 & 9,771 & 0,0157 & 116.9 & 32.6 \\
\hline Russian Fed. & 36.9 & 438 & 0 & 145,872 & 0,0030 & 8.9 & 39.6 \\
\hline France & 32.9 & 16,018 & 674 & 65,130 & 0,2459 & 118.9 & 42.3 \\
\hline India & 26.0 & 439 & 7 & $1,366,418$ & 0,0003 & 459.6 & 28.4 \\
\hline N. Zealand & 29.5 & 102 & 0 & 4,783 & 0,0213 & 18.2 & 38.0 \\
\hline Spain & 26.1 & 28,572 & 1,720 & 46,737 & 0,6113 & 93.7 & 44.9 \\
\hline Egypt & 14.3 & 294 & 10 & 100,388 & 0,0029 & 100.8 & 24.6 \\
\hline Maldives & 12.2 & 13 & 0 & 531 & 0,0245 & $1,769.9$ & 29.9 \\
\hline Sri Lanka & 13.8 & 87 & 0 & 21,324 & 0,0041 & 340.0 & 34.0 \\
\hline Turkey & 16.5 & 1,236 & 30 & 83,430 & 0,0148 & 108.4 & 31.5 \\
\hline Laos & 8.6 & 0 & 0 & 7,169 & 0,0000 & 31.1 & 24.4 \\
\hline Myanmar & 10.4 & 0 & 0 & 54,045 & 0,0000 & 82.7 & 29.0 \\
\hline
\end{tabular}

Source: CATO (2020); Lai et al. (2020b); UN (2019 and 2020); Vásquez and Porčnik (2019); WB (2020); WHO (2020a, b, and c).

* Covid-19 case and death statistics are from 23 March 2020. 
Table 1b. Key indicators for top 30 destination countries receiving air travellers from Wuhan, Hubei Province, China $(\mathrm{n}=30)$

\begin{tabular}{|c|c|c|c|c|}
\hline Country & $\begin{array}{r}\text { Human development } \\
\text { index }\end{array}$ & $\begin{array}{r}\text { Gross national } \\
\text { income }\end{array}$ & $\begin{array}{r}\text { Immigrant stock from China } \\
\text { (in thousand) }\end{array}$ & Human freedom index \\
\hline Thailand & 0.765 & 16,129 & 149,352 & 6.55 \\
\hline Japan & 0.915 & 40,799 & 741,022 & 8.28 \\
\hline Hong Kong & 0.939 & 60,221 & $2,343,868$ & 8.81 \\
\hline Taiwan & 0.882 & 28,128 & 0 & 8.4 \\
\hline South Korea & 0.906 & 36,757 & 656,846 & 8.2 \\
\hline USA & 0.920 & 56,140 & $2,130,352$ & 8.46 \\
\hline Malaysia & 0.804 & 27,227 & 54,980 & 6.52 \\
\hline Singapore & 0.935 & 83,793 & 462,632 & 8.11 \\
\hline Viet Nam & 0.693 & 6,220 & 8,639 & 6.29 \\
\hline Australia & 0.938 & 44,097 & 526,040 & 8.62 \\
\hline Indonesia & 0.707 & 11,256 & 73,971 & 6.83 \\
\hline Cambodia & 0.581 & 3,597 & 1,566 & 7.13 \\
\hline Macao, PRC & 0.907 & 79,110 & 290,609 & $\mathrm{n} / \mathrm{a}$ \\
\hline Germany & 0.939 & 46,946 & 129,150 & 8.53 \\
\hline Philippines & 0.712 & 9,540 & 37,083 & 6.88 \\
\hline UK & 0.920 & 39,507 & 226,000 & 8.47 \\
\hline Canada & 0.922 & 43,602 & 711,555 & 8.65 \\
\hline Italy & 0.883 & 36,141 & 212,173 & 8.04 \\
\hline UAE & 0.866 & 66,912 & 0 & 6.13 \\
\hline Russian Fed. & 0.824 & 25,036 & 56,210 & 6.34 \\
\hline France & 0.891 & 40,511 & 111,717 & 8.02 \\
\hline India & 0.647 & 6,829 & 7,035 & 6.64 \\
\hline N. Zealand & 0.921 & 35,108 & 98,109 & 8.88 \\
\hline Spain & 0.893 & 35,041 & 183,583 & 8.12 \\
\hline Egypt & 0.700 & 10,744 & 1,266 & 4.5 \\
\hline Maldives & 0.719 & 12,549 & 0 & $\mathrm{n} / \mathrm{a}$ \\
\hline Sri Lanka & 0.780 & 11,611 & 2,482 & 6.41 \\
\hline Turkey & 0.806 & 24,905 & 2,190 & 6.21 \\
\hline Laos & 0.604 & 6,317 & 13,951 & 6.2 \\
\hline Myanmar & 0.584 & 5,764 & 47,742 & 5.44 \\
\hline
\end{tabular}

Table 1c. Correlation matrix for the exploratory variables in top 30 destination countries $(n=30)$

\begin{tabular}{|c|c|c|c|c|c|c|c|c|c|c|}
\hline & $\begin{array}{c}\text { Total } \\
\text { Covid-19 } \\
\text { cases }\end{array}$ & $\begin{array}{c}\text { Total } \\
\text { deaths }\end{array}$ & $\begin{array}{c}\text { Total } \\
\text { population }\end{array}$ & $\begin{array}{c}\text { Population } \\
\text { density }\end{array}$ & $\begin{array}{l}\text { Median } \\
\text { age }\end{array}$ & $\begin{array}{c}\text { Human } \\
\text { development } \\
\text { index }\end{array}$ & $\begin{array}{c}\text { Gross } \\
\text { national } \\
\text { income }\end{array}$ & $\begin{array}{c}\text { Immigrant } \\
\text { stock } \\
\text { from } \\
\text { China }\end{array}$ & $\begin{array}{l}\text { Crude } \\
\text { rate of } \\
\text { spread }\end{array}$ & $\begin{array}{l}\text { Human } \\
\text { freedom } \\
\text { index }\end{array}$ \\
\hline Airline travellers' volume & -0.081 & -0.139 & -0.068 & 0.035 & $0.428^{*}$ & 0.258 & 0.163 & $0.409^{*}$ & -0.147 & 0.263 \\
\hline Total Covid-19 cases & 1 & $0.855^{* *}$ & 0.009 & -0.142 & $0.470^{* *}$ & 0.337 & 0.211 & 0.224 & $0.904^{* *}$ & 0.353 \\
\hline Total deaths & & 1 & -0.043 &,- 0.90 & $0.369^{*}$ & 0.182 & 0.076 & -0.002 & $0.930^{* *}$ & 0.194 \\
\hline Total population & & & 1 & -0.123 & -0.207 & -0.269 & -0.236 & -0.006 & -0.088 & -0.129 \\
\hline Population density & & & & 1 & 0.177 & 0.248 & $0.582^{* *}$ & 0.202 & -0.083 & 0.269 \\
\hline Median age & & & & & 1 & $0.845^{* *}$ & $0.632^{* *}$ & $0.413^{*}$ & $0.504^{* *}$ & $0.759^{* *}$ \\
\hline Human development index & & & & & & 1 & $0.823^{* *}$ & $0.467^{* *}$ & 0.321 & $0.776^{* *}$ \\
\hline Gross national income & & & & & & & 1 & $0.494^{* *}$ & 0.182 & $0.617^{* *}$ \\
\hline Immigrant stock from China & & & & & & & & 1 & 0.015 & $0.508^{* *}$ \\
\hline Crude rate of spread & & & & & & & & & 1 & 0.325 \\
\hline Human freedom index & & & & & & & & & & 1 \\
\hline
\end{tabular}


Table 2a. Moderating indicators by selected countries: Argentina to Latvia $(n=111)$ [23/03/2020]

\begin{tabular}{|c|c|c|c|c|c|}
\hline Country & $\begin{array}{r}\text { Total Covid-19 } \\
\text { cases } \\
\end{array}$ & Total deaths & $\begin{array}{r}\text { Total population } \\
\text { (in thousand) }\end{array}$ & $\begin{array}{r}\text { Population density } \\
\text { (persons per square km) }\end{array}$ & $\begin{array}{r}\text { Median age } \\
\text { (years) }\end{array}$ \\
\hline Argentina & 266 & 4 & 44,781 & 16.4 & 31.5 \\
\hline Algeria & 102 & 15 & 43,053 & 18.1 & 28.5 \\
\hline Australia & 1,709 & 7 & 25,203 & 3.3 & 37.9 \\
\hline Austria & 3,631 & 16 & 8,995 & 108.7 & 43.5 \\
\hline Azerbaijan & 65 & 1 & 10,048 & 121.6 & 32.3 \\
\hline Bahamas & 4 & 0 & 389 & 38.9 & 32.2 \\
\hline Bangladesh & 27 & 3 & 163,046 & $1,252.6$ & 27.6 \\
\hline Barbados & 17 & 0 & 287 & 667.5 & 40.5 \\
\hline Belgium & 3,401 & 75 & 11,539 & 381.1 & 41.9 \\
\hline Bhutan & 2 & 0 & 763 & 20.0 & 28.1 \\
\hline Bolivia & 27 & 0 & 11,513 & 10.6 & 25.6 \\
\hline Bosnia and Herzegovina & 125 & 1 & 3,301 & 64.7 & 43.1 \\
\hline Brazil & 1,546 & 25 & 211,050 & 25.3 & 33.5 \\
\hline Brunei Darussalam & 88 & 0 & 433 & 82.2 & 32.3 \\
\hline Bulgaria & 185 & 3 & 7,000 & 64.5 & 44.6 \\
\hline Cambodia & 86 & 0 & 16,487 & 93.4 & 25.6 \\
\hline Canada & 1,430 & 18 & 37,411 & 4.1 & 41.1 \\
\hline Central African Republic & 4 & 0 & 4,745 & 7.6 & 17.6 \\
\hline Chile & 632 & 1 & 18,952 & 25.5 & 35.3 \\
\hline Congo & 4 & 0 & 5,381 & 15.8 & 19.2 \\
\hline Costa Rica & 134 & 2 & 5,048 & 98.9 & 33.5 \\
\hline Croatia & 235 & 1 & 4,130 & 73.8 & 44.3 \\
\hline Cyprus & 95 & 0 & 1,199 & 129.7 & 37.2 \\
\hline Czechia & 1,165 & 1 & 10,689 & 138.4 & 43.2 \\
\hline Denmark & 1,395 & 13 & 5,772 & 136.0 & 42.3 \\
\hline Dominican Republic & 203 & 3 & 10,739 & 222.2 & 28.0 \\
\hline Ecuador & 789 & 14 & 17,374 & 70.0 & 27.9 \\
\hline Egypt & 294 & 10 & 100,388 & 100.8 & 24.6 \\
\hline El Salvador & 3 & 0 & 6,454 & 311.5 & 27.6 \\
\hline Estonia & 326 & 0 & 1,326 & 31.3 & 42.4 \\
\hline Fiji & 3 & 0 & 890 & 48.7 & 27.9 \\
\hline Finland & 626 & 1 & 5,532 & 18.2 & 43.1 \\
\hline France & 16,018 & 674 & 65,130 & 118.9 & 42.3 \\
\hline Gabon & 6 & 1 & 2,173 & 8.4 & 22.5 \\
\hline Georgia & 54 & 0 & 3,997 & 57.5 & 38.3 \\
\hline Germany & 24,774 & 94 & 83,517 & 239.6 & 45.7 \\
\hline Ghana & 24 & 1 & 30,418 & 133.7 & 21.5 \\
\hline Greece & 624 & 15 & 10,473 & 81.3 & 45.6 \\
\hline Guatemala & 19 & 1 & 17,581 & 164.1 & 22.9 \\
\hline Guinea & 2 & 0 & 12,771 & 52.0 & 18.0 \\
\hline Guyana & 5 & 1 & 783 & 4.0 & 26.7 \\
\hline Haiti & 2 & 0 & 11,263 & 408.7 & 24.0 \\
\hline Honduras & 27 & 0 & 9,746 & 87.1 & 24.3 \\
\hline Hungary & 167 & 7 & 9,685 & 107.0 & 43.3 \\
\hline Iceland & 568 & 1 & 339 & 3.4 & 37.5 \\
\hline India & 439 & 7 & $1,366,418$ & 459.6 & 28.4 \\
\hline Indonesia & 514 & 48 & 270,626 & 149.4 & 29.7 \\
\hline Ireland & 906 & 4 & 4,882 & 70.9 & 38.2 \\
\hline Israel & 1,071 & 1 & 8,519 & 393.7 & 30.5 \\
\hline Italy & 59,138 & 5476 & 60,550 & 205.9 & 47.3 \\
\hline Japan & 1,089 & 41 & 126,860 & 348.0 & 48.4 \\
\hline Jordan & 114 & 0 & 10,102 & 113.8 & 23.8 \\
\hline Kazakhstan & 60 & 0 & 18,551 & 6.9 & 30.7 \\
\hline Kenya & 15 & 0 & 52,574 & 92.4 & 20.1 \\
\hline Kyrgyzstan & 14 & 0 & 6,416 & 33.5 & 26.0 \\
\hline Latvia & 139 & 0 & 1,907 & 30.7 & 43.9 \\
\hline
\end{tabular}

Source: CATO (2020); UN (2019 and 2020); Vásquez and Porčnik (2019); WB (2020); WHO (2020a, b, and c). 
Table 2b. Moderating indicators by selected countries: Argentina to Latvia ( $\mathrm{n}=111)$ [23/03/2020]

\begin{tabular}{|c|c|c|c|c|c|}
\hline Country & $\begin{array}{r}\text { Human } \\
\text { development } \\
\text { index }\end{array}$ & $\begin{array}{r}\text { Gross } \\
\text { national } \\
\text { income }\end{array}$ & $\begin{array}{r}\text { Human } \\
\text { freedom } \\
\text { index }\end{array}$ & $\begin{array}{r}\text { Immigrant stock from } \\
\text { China } \\
\text { (in thousand) }\end{array}$ & $\begin{array}{r}\text { Immigrant stock in } \\
\text { China } \\
\text { (in thousand) }\end{array}$ \\
\hline Argentina & 0.830 & 17,611 & 6.86 & 15,924 & 1,933 \\
\hline Algeria & 0.759 & 13,639 & 4.99 & 683 & 554 \\
\hline Australia & 0.938 & 44,097 & 8.62 & 526,040 & 13,286 \\
\hline Austria & 0.914 & 46,231 & 8.48 & 15,986 & 1,054 \\
\hline Azerbaijan & 0.754 & 15,240 & 6.22 & 427 & 530 \\
\hline Bahamas & 0.805 & 28,395 & 7.56 & 179 & 0 \\
\hline Bangladesh & 0.614 & 4,057 & 5.77 & 174,487 & 6,282 \\
\hline Barbados & 0.813 & 15,912 & 7.02 & 43 & 0 \\
\hline Belgium & 0.919 & 43,821 & 8.29 & 19,813 & 1,578 \\
\hline Bhutan & 0.617 & 8,609 & 6.53 & 973 & 539 \\
\hline Bolivia & 0.703 & 6,849 & 6.65 & 1,173 & 175 \\
\hline Bosnia and Herzegovina & 0.769 & 12,690 & 7.37 & 18 & 0 \\
\hline Brazil & 0.761 & 14,068 & 6.48 & 23,769 & 115,347 \\
\hline Brunei Darussalam & 0.845 & 76,389 & 5.69 & 2,172 & 0 \\
\hline Bulgaria & 0.816 & 19,646 & 7.79 & 1,471 & 246 \\
\hline Cambodia & 0.581 & 3,597 & 7.13 & 1,566 & 464 \\
\hline Canada & 0.922 & 43,602 & 8.65 & 711,555 & 19,990 \\
\hline Central African Rep. & 0.381 & 777 & 5.41 & 127 & 0 \\
\hline Chile & 0.847 & 21,972 & 8.15 & 9,823 & 411 \\
\hline Congo & 0.608 & 5,804 & 5.36 & 937 & 870 \\
\hline Costa Rica & 0.794 & 14,790 & 7.70 & 9,422 & 107 \\
\hline Croatia & 0.837 & 23,061 & 7.86 & 434 & 136 \\
\hline Cyprus & 0.873 & 33,100 & 7.93 & 1,884 & 0 \\
\hline Czechia & 0.891 & 31,597 & 8.34 & 5,219 & 359 \\
\hline Denmark & 0.930 & 48,836 & 8.56 & 10,611 & 1,759 \\
\hline Dominican Republic & 0.745 & 15,074 & 6.95 & 4,995 & 0 \\
\hline Ecuador & 0.758 & 10,141 & 6.82 & 4,265 & 290 \\
\hline Egypt & 0.700 & 10,744 & 4.50 & 1,266 & 1,294 \\
\hline El Salvador & 0.667 & 6,973 & 6.89 & 260 & 0 \\
\hline Estonia & 0.882 & 30,379 & 8.46 & 312 & 0 \\
\hline Fiji & 0.724 & 9,110 & 7.17 & 935 & 136 \\
\hline Finland & 0.925 & 41,779 & 8.53 & 9,956 & 1,349 \\
\hline France & 0.891 & 40,511 & 8.02 & 111,717 & 15,087 \\
\hline Gabon & 0.702 & 15,794 & 5.99 & 331 & 150 \\
\hline Georgia & 0.786 & 9,570 & 7.74 & 256 & 0 \\
\hline Germany & 0.939 & 46,946 & 8.53 & 129,150 & 14,446 \\
\hline Ghana & 0.596 & 4,099 & 6.94 & 264 & 1,165 \\
\hline Greece & 0.872 & 24,909 & 7.33 & 4,414 & 370 \\
\hline Guatemala & 0.651 & 7,378 & 7.07 & 683 & 0 \\
\hline Guinea & 0.466 & 2,211 & 5.61 & 164 & 357 \\
\hline Guyana & 0.670 & 7,615 & 6.74 & 1,166 & 0 \\
\hline Haiti & 0.503 & 1,665 & 6.71 & 739 & 0 \\
\hline Honduras & 0.623 & 4,258 & 6.81 & 601 & 0 \\
\hline Hungary & 0.845 & 27,144 & 7.65 & 18,193 & 380 \\
\hline Iceland & 0.938 & 47,566 & 8.41 & 609 & 112 \\
\hline India & 0.647 & 6,829 & 6.64 & 7,035 & 15,051 \\
\hline Indonesia & 0.707 & 11,256 & 6.83 & 73,971 & 58,639 \\
\hline Ireland & 0.942 & 55,660 & 8.52 & 13,640 & 969 \\
\hline Israel & 0.906 & 33,650 & 7.61 & 1,130 & 757 \\
\hline Italy & 0.883 & 36,141 & 8.04 & 212,173 & 5,958 \\
\hline Japan & 0.915 & 40,799 & 8.28 & 741,022 & 66,159 \\
\hline Jordan & 0.723 & 8,268 & 6.84 & 20,936 & 864 \\
\hline Kazakhstan & 0.817 & 22,168 & 6.90 & 5,142 & 4,680 \\
\hline Kenya & 0.579 & 3,052 & 6.85 & 1,487 & 661 \\
\hline Kyrgyzstan & 0.674 & 3,317 & 6.98 & 303 & 988 \\
\hline $\begin{array}{l}\text { Latvia } \\
\text { L }\end{array}$ & 0.854 & 26,301 & 8.29 & 237 & 100 \\
\hline
\end{tabular}

Source: CATO (2020); UN (2019 and 2020); Vásquez and Porčnik (2019); WB (2020); WHO (2020a, b, and c). 
Table 2c. Moderating indicators by selected countries: Lebanon to Zambia ( $\mathrm{n}=111)$ [23/03/2020]

\begin{tabular}{|c|c|c|c|c|c|}
\hline Country & $\begin{array}{r}\text { Total Covid-19 } \\
\text { cases } \\
\end{array}$ & Total deaths & $\begin{array}{r}\text { Total population } \\
\text { (in thousand) }\end{array}$ & $\begin{array}{r}\text { Population density } \\
\text { (persons per square km) }\end{array}$ & $\begin{array}{r}\text { Median age } \\
\text { (years) }\end{array}$ \\
\hline Lebanon & 248 & 4 & 6,856 & 670.2 & 29.6 \\
\hline Lithuania & 143 & 1 & 2,760 & 44.0 & 45.1 \\
\hline Luxembourg & 798 & 8 & 616 & 237.7 & 39.7 \\
\hline Madagascar & 3 & 0 & 26,969 & 46.4 & 19.6 \\
\hline Malaysia & 1,306 & 10 & 31,950 & 97.2 & 30.3 \\
\hline Malta & 90 & 0 & 440 & $1,376.2$ & 42.6 \\
\hline Mauritania & 14 & 1 & 4,526 & 4.4 & 20.1 \\
\hline Mauritius & 28 & 2 & 1,270 & 625.5 & 37.5 \\
\hline Mexico & 316 & 2 & 127,576 & 65.6 & 29.2 \\
\hline Moldova & 94 & 1 & 4,043 & 123.1 & 37.6 \\
\hline Mongolia & 10 & 0 & 3,225 & 2.1 & 28.2 \\
\hline Myanmar & 0 & 0 & 54,045 & 82.7 & 29.0 \\
\hline Namibia & 3 & 0 & 2,495 & 3.0 & 21.8 \\
\hline Nepal & 1 & 0 & 28,609 & 199.6 & 24.6 \\
\hline Netherlands & 4,217 & 179 & 17,097 & 507.0 & 43.3 \\
\hline New Zealand & 102 & 0 & 4,783 & 18.2 & 38.0 \\
\hline Norway & 2,132 & 7 & 5,379 & 14.7 & 39.8 \\
\hline Pakistan & 784 & 5 & 216,565 & 280.9 & 22.8 \\
\hline Panama & 313 & 3 & 4,246 & 57.1 & 29.7 \\
\hline Papua New Guinea & 1 & 0 & 8,776 & 19.4 & 22.4 \\
\hline Paraguay & 22 & 1 & 7,045 & 17.7 & 26.3 \\
\hline Peru & 363 & 5 & 32,510 & 25.4 & 31.0 \\
\hline Philippines & 380 & 25 & 108,117 & 362.6 & 25.7 \\
\hline Poland & 634 & 7 & 37,888 & 123.7 & 41.7 \\
\hline Portugal & 1,600 & 14 & 10,226 & 111.7 & 46.2 \\
\hline Romania & 433 & 2 & 19,365 & 84.1 & 43.2 \\
\hline Russian Federation & 438 & 0 & 145,872 & 8.9 & 39.6 \\
\hline Rwanda & 19 & 0 & 12,627 & 511.8 & 20.0 \\
\hline Serbia & 188 & 1 & 8,772 & 100.3 & 41.6 \\
\hline Seychelles & 7 & 0 & 98 & 212.5 & 34.2 \\
\hline Singapore & 455 & 2 & 5,804 & $8,291.9$ & 42.2 \\
\hline Slovakia & 185 & 0 & 5,457 & 113.5 & 41.2 \\
\hline Slovenia & 414 & 1 & 2,079 & 103.2 & 44.5 \\
\hline South Africa & 274 & 0 & 58,558 & 48.3 & 27.6 \\
\hline South Korea & 8,961 & 113 & 51,225 & 526.8 & 43.7 \\
\hline Spain & 28,572 & 1720 & 46,737 & 93.7 & 44.9 \\
\hline Sri Lanka & 87 & 0 & 21,324 & 340.0 & 34.0 \\
\hline Sudan & 2 & 1 & 42,813 & 24.3 & 19.7 \\
\hline Suriname & 5 & 0 & 581 & 3.7 & 29.0 \\
\hline Sweden & 1,906 & 21 & 10,036 & 24.5 & 41.1 \\
\hline Switzerland & 6,971 & 60 & 8,591 & 217.4 & 43.1 \\
\hline Thailand & 721 & 1 & 69,626 & 136.3 & 40.1 \\
\hline Timor-Leste & 1 & 0 & 1,293 & 87.0 & 20.8 \\
\hline Togo & 16 & 0 & 8,082 & 148.6 & 19.4 \\
\hline Trinidad and Tobago & 50 & 0 & 1,395 & 271.9 & 36.2 \\
\hline Turkey & 1,236 & 30 & 83,430 & 108.4 & 31.5 \\
\hline Uganda & 1 & 0 & 44,270 & 221.6 & 16.7 \\
\hline Ukraine & 47 & 3 & 43,994 & 75.9 & 41.2 \\
\hline United Kingdom & 5,683 & 281 & 67,530 & 279.1 & 40.5 \\
\hline U. Rep. of Tanzania & 12 & 0 & 58,005 & 65.5 & 18.0 \\
\hline United States of America & 35,206 & 471 & 329,065 & 36.0 & 38.3 \\
\hline Uruguay & 158 & 0 & 3,462 & 19.8 & 35.8 \\
\hline Venezuela & 36 & 0 & 28,516 & 32.3 & 29.6 \\
\hline Vietnam & 118 & 0 & 96,462 & 311.1 & 32.5 \\
\hline Zambia & 3 & 0 & 17,861 & 24.0 & 17.6 \\
\hline
\end{tabular}


Table 2d. Moderating indicators by selected countries: Lebanon to Zambia ( $\mathrm{n}=111)$ [23/03/2020]

\begin{tabular}{|c|c|c|c|c|c|}
\hline Country & $\begin{array}{c}\text { Human } \\
\text { development } \\
\text { index }\end{array}$ & $\begin{array}{l}\text { Gross national } \\
\text { income }\end{array}$ & $\begin{array}{l}\text { Human } \\
\text { freedom } \\
\text { index }\end{array}$ & $\begin{array}{l}\text { Immigrant stock from China } \\
\text { (in thousand) }\end{array}$ & $\begin{array}{l}\text { Immigrant stock } \\
\text { in China (in } \\
\text { thousand) }\end{array}$ \\
\hline Lebanon & 0.730 & 11,136 & 6.74 & 2,987 & 399 \\
\hline Lithuania & 0.869 & 29,775 & 8.32 & 280 & 100 \\
\hline Luxembourg & 0.909 & 65,543 & 8.56 & 1,117 & 0 \\
\hline Madagascar & 0.521 & 1,404 & 6.32 & 2,813 & 238 \\
\hline Malaysia & 0.804 & 27,227 & 6.52 & 54,980 & 10,954 \\
\hline Malta & 0.885 & 34,795 & 8.37 & 447 & 0 \\
\hline Mauritania & 0.527 & 3,746 & 5.47 & 346 & 204 \\
\hline Mauritius & 0.796 & 22,724 & 7.52 & 23,210 & 660 \\
\hline Mexico & 0.767 & 17,628 & 6.65 & 8,860 & 1,261 \\
\hline Moldova & 0.711 & 6,833 & 6.93 & 361 & 137 \\
\hline Mongolia & 0.735 & 10,784 & 7.61 & 9,683 & 4,546 \\
\hline Myanmar & 0.584 & 5,764 & 5.44 & 47,742 & 39,776 \\
\hline Namibia & 0.645 & 9,683 & 6.75 & 2,881 & 134 \\
\hline Nepal & 0.579 & 2,748 & 6.51 & 24,394 & 2,401 \\
\hline Netherlands & 0.933 & 50,013 & 8.50 & 54,413 & 3,378 \\
\hline New Zealand & 0.921 & 35,108 & 8.88 & 98,109 & 3,656 \\
\hline Norway & 0.954 & 68,059 & 8.44 & 11,520 & 850 \\
\hline Pakistan & 0.560 & 5,190 & 5.69 & 312 & 7,746 \\
\hline Panama & 0.795 & 20,455 & 7.69 & 19,273 & 905 \\
\hline Papua New Guinea & 0.543 & 3,686 & 6.60 & 92 & 100 \\
\hline Paraguay & 0.724 & 11,720 & 6.90 & 800 & 0 \\
\hline Peru & 0.759 & 12,323 & 7.55 & 4,751 & 21,641 \\
\hline Philippines & 0.712 & 9,540 & 6.88 & 37,083 & 121,320 \\
\hline Poland & 0.872 & 27,626 & 7.78 & 1,262 & 794 \\
\hline Portugal & 0.850 & 27,935 & 8.27 & 10,806 & 375 \\
\hline Romania & 0.816 & 23,906 & 8.11 & 4,909 & 460 \\
\hline Russian Federation & 0.824 & 25,036 & 6.34 & 56,210 & 9,714 \\
\hline Rwanda & 0.536 & 1,959 & 6.82 & 105 & 176 \\
\hline Serbia & 0.799 & 15,218 & 7.30 & 1,750 & 149 \\
\hline Seychelles & 0.801 & 25,077 & 7.16 & 515 & 0 \\
\hline Singapore & 0.935 & 83,793 & 8.11 & 462,632 & 12,191 \\
\hline Slovakia & 0.857 & 30,672 & 8.02 & 1,135 & 203 \\
\hline Slovenia & 0.902 & 32,143 & 7.97 & 1,038 & 0 \\
\hline South Africa & 0.705 & 11,756 & 7.08 & 38,684 & 1,925 \\
\hline South Korea & 0.906 & 36,757 & 8.20 & 656,846 & 222,276 \\
\hline Spain & 0.893 & 35,041 & 8.12 & 183,583 & 3,425 \\
\hline Sri Lanka & 0.780 & 11,611 & 6.41 & 2,482 & 6,361 \\
\hline Sudan & 0.507 & 3,962 & 4.44 & 1,310 & 0 \\
\hline Suriname & 0.724 & 11,933 & 7.48 & 5,436 & 105 \\
\hline Sweden & 0.937 & 47,955 & 8.50 & 28,410 & 2,566 \\
\hline Switzerland & 0.946 & 59,375 & 8.82 & 22,286 & 1,348 \\
\hline Thailand & 0.765 & 16,129 & 6.55 & 149,352 & 23,357 \\
\hline Timor-Leste & 0.626 & 7,527 & 6.76 & 1,249 & 0 \\
\hline Togo & 0.513 & 1,593 & 6.31 & 530 & 191 \\
\hline Trinidad and Tobago & 0.799 & 28,497 & 6.62 & 871 & 0 \\
\hline Turkey & 0.806 & 24,905 & 6.21 & 2,190 & 1,750 \\
\hline Uganda & 0.528 & 1,752 & 6.61 & 597 & 321 \\
\hline Ukraine & 0.750 & 7,994 & 6.26 & 6,625 & 1,437 \\
\hline United Kingdom & 0.920 & 39,507 & 8.47 & 226,000 & 12,623 \\
\hline United Republic of Tanzania & 0.528 & 2,805 & 6.26 & 22,542 & 498 \\
\hline United States of America & 0.920 & 56,140 & 8.46 & $2,130,352$ & 71,493 \\
\hline Uruguay & 0.808 & 19,435 & 7.74 & 165 & 0 \\
\hline Venezuela & 0.726 & 9,070 & 3.80 & 14,081 & 2,127 \\
\hline Vietnam & 0.693 & 6,220 & 6.29 & 8,639 & 36,205 \\
\hline Zambia & 0.591 & 3,582 & 6.49 & 1,055 & 310 \\
\hline
\end{tabular}

Source: CATO (2020); UN (2019 and 2020); Vásquez and Porčnik (2019); WB (2020); WHO (2020a, b, and c). 